\title{
BRUTALNA KAMPANIA ILUSTROWANEGO KURIERA CODZIENNEGO PRZECIWKO WLADYSŁAWOWI GRABSKIEMU I WYMIANIE WALUT W 1919 ROKU
}

\author{
Andrzej J. Madera \\ orcid.org/0000-0001-5281-1743 \\ Instytut Prawa, Administracji i Ekonomii \\ Uniwersytet Pedagogiczny im. KEN w Krakowie
}

\begin{abstract}
A Brutal Campaign Against Władysław Grabski and His Monetary Reform of 1919 as Presented in the Ilustrowany Kurier Codzienny Daily Newspaper
\end{abstract}

The unification process of the Polish state after 1918 called for some prompt and decisive measures and persistency in overcoming the post-partition differences and idiosyncrasies. The article presents the attitude of the Ilustrowany Kurier Codzienny, a daily newpaper which deemed itself a representative of the interests of the people living in the Lesser Poland region (Małopolska, i.e. south-central Poland) towards the currency unification reform introduced in 1919. It shows how complex this reform was and how much criticism was directed at those behind it. The article focuses on the criticism from the Ilustrowany Kurier Codzienny, the measures the journalists took in order to fight both the unfavorable reformatory solutions and the politicians who prepared them. Particular attention is paid to the newspaper's attitude towards Władysław Grabski, who was the Minister of Finance and Prime Minister in the period under investigation, i.e. between the 1st of January 1919 and the end of 1920.

Keywords: monetary reform of 1919, reconstruction of the state, Władysław Grabski, pre-war press, Ilustrowany Kurier Codzienny

\section{Wprowadzenie}

Odzyskanie niepodległości w 1918 roku postawiło przed polskim państwem wiele trudnych do rozwiązania problemów społecznych i gospodarczych. Do najpilniejszych, umożliwiających budowanie zrębów państwowości i podstaw gospodarki zaliczono uporządkowanie zastanego systemu walutowego i podatkowego (Grata 
2009, s. 7). Reformy przeprowadzano pod naciskiem tragicznej sytuacji gospodarczej, inflacji oraz kryzysu w zaopatrzeniu ludności. Dopełnieniem tego trudnego położenia były nieuregulowane sprawy terytorialne, intensywnie prowadzone spory i konflikty o ustalenie ostatecznych granic państwa ${ }^{1}$. W sferze finansowo-walutowej wyzwaniem okazywało się ustalenie wymienialności walut funkcjonujących na polskich ziemiach, będących środkami płatniczymi zaborców. Zostawione przez nich systemy walutowe okazały się „odziedziczoną” częścią życia gospodarczego, mimo że wcześniej zostały rozprzężone przez pierwszą wojnę światową, przesunięcia granic, brak ładu i porządku w Europie.

W 1916 roku zmiany terytorialne wynikające z działań wojennych doprowadziły do zdominowania dużej części terytorium przyszłego państwa polskiego przez władze koalicji Niemiec i Austrio-Węgier, na którym utworzono tzw. Generalne Gubernatorstwo Warszawskie. Potwierdzeniem dominacji wymienionych państw na nowo utworzonym obszarze było wprowadzenie 9 grudnia 1916 roku jedynej oficjalnej waluty, marki polskiej, dzielącej się na 100 fenigów. W 1918 roku na terenie nowego państwa oprócz marki polskiej znajdowały się także waluty Cesarstwa Niemiec (marka Rzeszy), Cesarstwa Austro-Węgier (korona austriacka) i Cesarstwa Rosji (rubel). I nie były to wszystkie środki pieniężne znajdujące się w obiegu. Taki stan wymagał zmiany, choć społeczeństwo w większości przystosowało się do tych walut. W praktyce płacono wieloma walutami, nie tylko państw zaborczych (Kowalski 2018).

Odrodzone państwo uznało markę polską za swoją pierwszą oficjalną, choć przejściową walutę. Korzystanie z niej wynikało z kilku przyczyn. Pierwszą było rozpowszechnienie tej waluty na całym terytorium państwa, drugą przyznanie 6 grudnia 1918 roku Polskiej Krajowej Kasie Pożyczkowej, czyli instytucji powołanej przez Niemców, statusu tymczasowego polskiego banku centralnego. Ponadto w skarbcach Kasy znajdowały się znaczne zapasy banknotów, dających się możliwie szybko wykorzystać, co w znacznym stopniu obniżało koszty całej pieniężnej operacji. W grudniu 1918 roku marka polska stała się oficjalną walutą Rzeczypospolitej (Głowacki 2018), ale środkiem płatniczym została ona dopiero 15 stycznia 1920 roku (Drozdowski 2002, s. 86). Wprowadzenie jednej waluty miało wymiar symboliczny, było widocznym znakiem odrodzenia się państwa.

Pomimo wprowadzenia oficjalnej waluty na terytorium Polski w obiegu dalej krążyły waluty byłych zaborców. Ich funkcjonowanie, po bardzo różnych kursach, hamowało rozwój gospodarczy i przyczyniało się do wzrostu chaosu finansowego, spekulowania oraz inflacji. W 1919 roku kurs marki polskiej do dolara wynosił 110 marek, a w 1920 roku już 590 marek (Zieleń 2010, s. 11). Doprowadziło to do przewożenia walut $\mathrm{z}$ terytorium jednego byłego zaboru do drugiego, by sprzedać je z zyskiem. Dorabianie się na różnicach kursowych świadczyło o patologii gospodarczej i słabości państwa. Wycofanie walut zaborców i umocnienie jednolitej waluty stało się zatem istotnym wyzwaniem dla rządzących w pierwszych latach niepodległości.

1 W obronie polskich interesów występowała prasa, w tym krakowski IKC (Borowiec 2005c, s. 560). 
Prezentowany artykuł ma przedstawić problemy związane z wprowadzeniem jednej waluty. To ujednolicenie proponowane przez pierwszych ministrów skarbu wywołało negatywną kampanię prasową prowadzoną m.in. przez dziennik Mariana Dąbrowskiego (Bańdo 2003) Ilustrowany Kurier Codzienny (IKC), która pozostawała w zgodzie z przyjętym przez właściciela IKC aktywnym sposobem oddziaływania na politykę i społeczeństwo (Borowiec 2010, s. 46). Niniejsza praca omówi stosunek tego dziennika do wprowadzanych rozwiązań walutowych oraz ukaże skalę nagonki prasowej wymierzonej przeciwko Władysławowi Grabskiemu, który $\mathrm{w}$ analizowanym okresie odpowiadał za politykę gospodarczą, w tym unifikację walut, zahamowanie spekulacji oraz walkę z inflacją.

Przedstawiona analiza dotyczy okresu od 1 stycznia 1919 do 31 grudnia 1920 roku i przedstawia nie tylko sposoby prowadzenia kampanii wymierzonej w liczącego się w okresie międzywojennym polityka, odpowiedzialnego za sprawy gospodarcze państwa. Pokazuje także, jak gwałtownie odradzały się separatyzmy dzielnicowe, gdy pojawiała się rzeczywista potrzeba uporządkowania i ujednolicenia spraw gospodarczych pomiędzy byłymi dzielnicami zaborczymi. Artykuł wykazuje również, że interesy ekonomiczne poszczególnych regionów oraz ich obrona okazywały się często ważniejsze niż dobro wspólne odrodzonego państwa.

Należy dodać, że wprowadzane rozwiązania walutowe wpływały na kondycję finansową wydawnictwa Mariana Dąbrowskiego (Borowiec 2003, s. 229). Dlatego też IKC, dziennik sensacyjno-informacyjny i patriotyczno-narodowy (Borowiec 2005a, s. 28-31), często przyjmował takie partykularne, instrumentalne stanowisko. Nie przeszkadzało mu to w namawianiu do zgody i wspólnego odbudowywania państwa. W licznych odredakcyjnych tekstach $I K C$ nawoływał do odzyskania niepodległości (zob. np. Dokąd..., 1912; Państwowość..., 1916; Polska..., 1918), a gdy to nastąpiło, podkreślał z patosem: „Nie krytykanctwem, frazeologią, nie słowem, lecz czynem stwierdzić musimy naszą miłość Ojczyzny i dbałość o Jej dobro wspólne dobro" ((p) 1924).

\section{Początki konfliktu pomiędzy IKC a „rządem warszawskim”}

12 czerwca 1919 roku IKC podkreślał: „Unifikacja waluty w Polsce staje się najbardziej palącą kwestią dnia" (Przyspieszyć..., 1919). W tym samym artykule dziennik domagał się zdecydowanych działań, nie pozostawiał wątpliwości co do potrzeby takiego kroku i potępiał tych, którzy wstrzymywali zmiany. Należało przyspieszyć unifikację, gdyż tego wymagała sytuacja finansowa i gospodarcza państwa. W przypadku braku takich działań jedynym rozwiązaniem stawała się dymisja ówczesnego ministra skarbu Stanisława Karpińskiego, który zdaniem IKC chciał „ukarać Galicję, że należała do Austrii” (Pomysły..., 1919). Tak mocny nacisk na uporządkowanie sytemu walut świadczył o zaangażowaniu IKC oraz świadomości potrzeby wyeliminowania chaosu walutowego. Dziennik pozytywnie odbierał początkowe działania prowadzące do ujednolicenia wymiany walutowej, czego przykładem może być popieranie blokady dopływu z zagranicy walut państw zaborczych czy ustalenie 
okresowej dwuwalutowości polegającej na określeniu wzajemnego kursu marki polskiej do innych walut. Wspierano także kwestię „realizacji zadłużeń w tych walutach. Miały one być spłacone w markach polskich, według przyjętego, stałego kursu tych walut" (Sułkowska 1990, s. 56).

Taka propaństwowa postawa nie była jednak stałym elementem na stronach dziennika. IKC budował swoją pozycję u czytelników krytycznym podejściem do rzeczywistości. Od początku 1919 roku coraz częściej krytykował posunięcia rządu Ignacego Paderewskiego. $Z$ rozczarowaniem pisał:

Nie mija dzień, nie może wyjść jeden numer IKC abyśmy nie musieli z bólem serca podać nowej wiązanki faktów, świadczących o nieumiejętności, niedołęstwie, chaotyczności, a czasem czegoś bardziej zbliżonego do złej woli, ze strony warszawskich sfer rządzących (Nakaz..., 1919).

Przykładem może być także reakcja redakcji na informację o projektach Ministerstwa Handlu i Przemysłu w sprawie ujednolicenia nowej taryfy celnej dla wszystkich dzielnic. Przyjęta taryfa miała sprzyjać kongresówce, za podstawę uznano bowiem najdroższą w świecie taryfę rosyjską, z 200-procentowym dodatkiem. Taki przelicznik zdaniem IKC miał wywołać trzy razy większą drożyznę oraz doprowadzić Małopolskę do zupełnej ruiny gospodarczej. Jak pokazuje analiza artykułów z początku 1919 roku, wsparcie ze strony IKC otrzymywały tylko te inicjatywy finansowe i gospodarcze rządu, które były korzystne lub przynajmniej neutralne dla interesów mieszkańców Małopolski.

11 lipca 1919 roku został politycznie zaatakowany rząd Ignacego Paderewskiego za podpisanie traktatu o mniejszościach narodowych ${ }^{2}$. Wsparcia nie udzielił także IKC, który już wcześniej coraz częściej odcinał się od tego gabinetu, nazywając go „warszawskim rządem”. Jednak możliwość jego upadku i powołania następnego, w grudniu 1919 roku, nie wywołała entuzjazmu IKC. Okazało się, że IKC nie był zainteresowany zmianami na stanowisku ministra skarbu. Dziennik jednoznacznie opowiedział się za Leonem Bilińskim, kolejnym ministrem w rządzie Paderewskiego: „Stwierdzamy tylko, że ze wszystkich fachowców dr Biliński jest - zwłaszcza na obecną chwilę - najodpowiedniejszy" (Zwycięstwo..., 1919). Uczyniono go symbolem obrony polskiego budżetu, przedstawicielem koncepcji, żeby kasa państwowa miała jednego gospodarza, aby służyła tylko państwu, a nie lokalnym, szczególnie warszawskim grupom interesu. Dziennik pokładał w ministrze ogromne nadzieje.

Powszechnie sądziliśmy, że najwybitniejszy i najbardziej fachowy minister w gabinecie p. Paderewskiego dr Leon Biliński, światowej sławy znawca waluty i polityki finansowej państwa, utrzyma się przy władzy ze względu na to, że jest wprost niezbędny i nie do zastąpienia i że jest jedynym specjalistą, który oczyści stajnię Augiasza i zaprowadzi porządki w Warszawie europejskie, powtarzamy

2 Chodzi o tzw. mały traktat wersalski, podpisany przez Polskę 28 czerwca 1919 roku. Gwarantował on poszanowanie i obronę praw mniejszości narodowych zamieszkujących Polskę. 
europejskie stosunki w gospodarce finansowej naszej młodej republiki (Po ustapieniu..., 1919).

Odchodzący minister skarbu został przedstawiony jako obrońca interesów finansowych mieszkańców całego państwa.

Chciał unifikacji i ustalenia waluty, aby naprawdę była środkiem wymiennym o stałej wartości, a nie ciągle spadającym, w cenie materiału spekulacyjnego dla bankierów warszawskich, którzy jeżdżąc pomiędzy Krakowem i Warszawą, robią na różnicy kursu miliony (Zwycięstwo..., 1919).

Biliński miał chronić interesy Małopolski, walcząc o podwyższenie kursu korony, a tym samym osłabienie marki polskiej. Miały o tym świadczyć działania ministra, o których rozpisywała się prasa warszawska. Ataki tej prasy, rozpuszczane plotki, rzekome lub domniemane afery, w które podobno był zamieszany minister, stanowiły jakoby dowód jego nieprzejednanej postawy, odwagi i chęci uzdrowienia finansów budżetu państwa (Po ustąpieniu..., 1919). Dlatego zmiana gabinetu rządowego budziła w IKC-u niepokój. Przewidując upadek rządu, IKC pisał z goryczą i rezygnacją: „Nie jest pocieszający przebieg warszawskiego przesilenia. Za wiele w nim ... Warszawy" (Zwycięstwo..., 1919).

\section{Przyczyny ataku IKC na Władysława Grabskiego}

Pierwsza reakcja dziennika na powołanie na stanowisko ministra skarbu Władysława Grabskiego w gabinecie Leopolda Skulskiego była wyjątkowo przyjazna. W artykule przedstawiającym skład nowego rządu redakcja widziała w postaci nowego ministra skarbu znanego ekonomistę, który zyskał sobie uznanie jako wytrawny znawca spraw finansowych. Przedstawiała go w roli głównego delegata polskiego do spraw ekonomicznych na konferencję w Paryżu, człowieka umiarkowanego, niemającego nic wspólnego z Narodową Demokracją, raczej konserwatystę (Skład..., 1919).

Jednak szybko, bo już dwa dni później, stanowisko IKC zostało zaprezentowane w całej pełni. W artykule przewodnim poinformowano czytelników, że nowy minister z całych sił nienawidzi Galicji i chce ją ukarać za jej wcześniejszą przynależność do Austrii. Dziennik twierdził, że takie podejście Grabski miał już głosić w czasie konferencji paryskiej. Nie tracono jednak całkowicie nadziei, wyrażano ufność, że nowy minister pójdzie śladami swego poprzednika, uzna jego program za własny i w ten sposób walutę i finanse wyprowadzi z chaosu (Po ustąpieniu..., 1919).

Nadzieje te nie trwały długo i w krótkim czasie zostały rozwiane. Świeżo powołany minister skarbu ogłosił dwa nowe rozporządzenia finansowe. Pierwsze wzywało wszystkich posiadaczy koron w ilości ponad 10 tysięcy do składania tychże w kasach skarbowych, a drugie ustalało relację marki polskiej do korony w stosunku: 1 korona = 70 fenigów (Rozporządzenia..., 1919). Oba wywołały gwałtowne reakcje ze strony sfer finansowych, zaniepokojenie oraz oskarżenia o niedoszacowanie korony 
i przeszacowanie marki polskiej. Według IKC już w lipcu 1919 roku przelicznik ten należało uznać za niekorzystny dla posiadaczy koron. Kurs „został ustalony na podstawie wadliwych, krzywdzących przeliczników, dlatego cała Małopolska miała na tym stracić" (Borowiec 2015b, s. 145). Podkreślano:

Skoro zaś na wszelki wypadek korona jest zdrowszą od marki polskiej, potrzeba specjalnej dyspozycji umysłu, aby zrozumieć dlaczego zgoła niezdrowa marka ma pochłonąć co prawda kulejącą, ale przecież jeszcze ruszającą się koronę. Łatwiej byłoby już przeto pojąć, gdyby pierwszy etap unifikacji waluty polskiej polegał na usunięciu beznadziejnej na rynku światowym marki polskiej (Rozporządzenia..., 1919).

Natychmiastowa reakcja giełdy warszawskiej, która ustaliła kurs „1 korona = 83 fenigi!", o czym poinformował IKC na pierwszej stronie, doprowadziła do natężenia ataków skierowanych na ministra. Argument, że rynek sam obalił wyceny dokonane przez ministra, miał potwierdzać opinie galicyjskich finansistów oraz dzienników prasowych. „Bańki mydlane p. Grabskiego pryskają. Amatorskie eksperymenty zawiodły na całej linii [...]. Grabski prawdopodobne nie widzi jeszcze nic" (1 korona..., 1919). Zwycięstwo dziennika okazało się jeszcze bardziej znaczące, bo na początku stycznia 1920 roku giełda rozstrzygnęła rywalizację prowadzoną pomiędzy koroną a marką, a tym samym pomiędzy IKC i ministrem. Kurs giełdowy został ustalony na poziomie: 1 marka $=1$ korona 15 halerzy $(1$ marka..., 1919).

Rozstrzygnięcia giełdowe legitymizowały kolejne ataki na ministra skarbu, które właściwie od końca grudnia 1919 roku prowadzone były codziennie. Sugerowano, że niekorzystne rozwiązania finansowe dla Małopolski doprowadzą w mającym się odbyć plebiscycie do odwrócenia się od Polski mieszkańców Śląska Cieszyńskiego. Miały one godzić w "najżywotniejsze interesy całego byłego zaboru austriackiego, a więc i Śląska" (Dr.J.H. 1919). Podobne zaniepokojenie budziły eksperymenty ministra wśród ludności w Małopolsce. Według dziennika uderzały bowiem w interesy zarówno producentów, jak i konsumentów tej dzielnicy bezpośrednio, a pośrednio zagrażały finansowym interesom całego kraju (Małopolska..., 1920).

W styczniu 1920 roku ataki na ministra skarbu kontynuowano. Ukazywały się kolejne drobne notatki i artykuły wymierzone w Grabskiego. Dziennik bez najmniejszych skrupułów przypisywał ministrowi sprawstwo wszelkich niekorzystnych zdarzeń, nieszczęść czy katastrof gospodarczych. Zarzucał mu kłamstwo (Pan Grabski mówi..., 1920), wywołanie strajku kolejarzy we Lwowie (Skutki..., 1920), oskarżano jego współpracowników i sojuszników politycznych. Zaatakowano Wincentego Witosa, że jakoby zawarł z ministrem pakt i „dla swoich osobistych korzyści politycznych, dla wpływów, dla utrzymania swej większości sejmowej [...] zaprzedał interesy Małopolski, a zwłaszcza ludu włościańskiego w Galicji” (Witos, Grabski..., 1920). Kluczowy zarzut wobec ministra został sformułowany już na początku stycznia 1920 roku, gdy doszło do ustalenia relacji pomiędzy marką polską a koroną przez warszawską giełdę. Fakt ten nie pozostawiał wątpliwości, minister popełnił błędy i powinien podać się do dymisji. Ten argument powtarzany 
był później wielokrotnie, za każdym razem przypominano o szkodach wyrządzonych galicyjskiemu społeczeństwu. „Należy się więc ratować, a jedynym ratunkiem jest natychmiastowa dymisja p. Grabskiego i oddanie tej najważniejszej teki w ręce człowieka, który umie liczyć i wie co robi” (P. Grabski tworzy..., 1920).

Walka o lepszy przelicznik pomiędzy koroną a marką polską wywołała także ataki ze strony środowisk pochodzących $\mathrm{z}$ kongresówki. IKC odpierał je, podkreślając, że nie walczy o koronę jako o „znak pieniędzy byłej monarchii austro-węgierskiej, państwa, które zniknęło z powierzchni ziemi i dla nas, jak i dla wielu innych narodów, jest już tylko koszmarem przeszłości, ciężkim wspomnieniem niewoli i kajdan" (Czy walczymy..., 1920), a dąży wytrwale do zaprowadzenia sprawiedliwego obciążenia finansowego i podatkowego, obejmującego równomiernie poszczególne dawne terytoria państw zaborczych. Podkreślano, że Grabski skrzywdził swoją lekkomyślnością i decyzjami nie tylko Małopolskę, ale także całe państwo. W wyniku ustalonej relacji pomiędzy koroną a marką wszyscy w Małopolsce odczuwają drożyznę. Sytuację powstałej pułapki pieniężnej doskonale opisuje niniejszy fragment:

Za marki według urzędowej relacji na razie dostać można jedynie wódkę [...]. Trudno jednak całe społeczeństwo małopolskie zakwaterować w szynku. Wytwarza się sytuacja nieznośna. Jest tylko jedna droga, która doprowadzi do rozwiązania: skoro ustalono relację, nawet tak złą jak nasza, trzeba iść konsekwentnie dalej. I usunąć koronę z obiegu, dając w zamian markę polską. [...] Precz z koroną! O usunięcie tego austriackiego znaczka pieniężnego walczymy od piętnastu miesięcy. [...] Straty te już ponieśliśmy. Teraz więc dla uniknięcia chaosu, w imię interesów całego państwa [...] żądamy natychmiastowego wycofania korony z obiegu i zastąpienia marką polską" (Precz z koroną..., 1920).

Tak ostre teksty IKC doprowadziły 13 lutego 1920 roku do ingerencji cenzury w związku z krytycznym artykułem o ministrze skarbu (Dziki, Rogoż, 2010, s. 83).

W następnych miesiącach na łamach $I K C$ dominowały relacje o wojnie z Rosją bolszewicką. Konflikt z ministrem zszedł na drugi plan. Ataki na niego pojawiały się rzadko, aż do czasu informacji o ewentualnym upadku rządu Leopolda Skulskiego oraz formowaniu się nowego, w którym Władysław Grabski znowu byłby ministrem skarbu (Cały gabinet..., 1920). IKC uderzył z całej mocy, by uniemożliwić sprawowanie funkcji przez Grabskiego w nowym rządzie. Nie akceptował sytuacji, w której Grabski miałby nadal piastować stanowisko ministra skarbu.

Dziwną doprawdy jest rzeczą, że sfery kierujące nie chcą sobie zdać sprawy z całej szkodliwości p. Wł. Grabskiego. Za p. ministrem skarbu ciągnie się już łańcuch zarządzeń, na których straciło państwo, stracili uczciwi obywatele, a zarobili spekulanci" (Minister..., 1920).

IKC przypominał nieudane działania, m.in. pomysł wprowadzenia przymusowej „Pożyczki Odrodzenia” na potrzeby państwa walczącego z Rosją bolszewicką. 
Nawoływał do zastanowienia i opamiętania, przypominał, że istnieją dzienniki prasowe, które minister powinien czytać i korzystać z pojawiających się w nich rad.

Panie ministrze skarbu! Jeśli pan zostanie nadal na swym ważnym posterunku, co jest dla kraju ewentualnością bardzo przykrą, może pan zechce czytywać dzienniki, które pana nie chwalą, a po obywatelsku wykazują pańskie błędy" (Minister..., 1920).

Kryzys polityczny i prowadzona wojna generowały przeszkody w formowaniu nowego gabinetu. Ostatecznie doszło do utworzenia rządu Władysława Grabskiego, nazwanego przez IKC „gabinetem konieczności państwowych” (T.zw.., 1920), w którym Grabski sprawował funkcję ministra skarbu (Nowy..., 1920; Jak powstał..., 1920). Nawoływania dziennika do złożenia przez niego rezygnacji ze stanowiska ministra w rządzie, w którym był premierem, na nic się zdały.

Pozapartyjny rząd Wł. Grabskiego - wspominał Maciej Rataj - słaby pod względem doboru ludzi, pozbawiony oparcia w społeczeństwie, zaledwie tolerowany przez Sejm jako tymczasowe zło konieczne, mało był dopasowany do sytuacji, w jakiej znajdowało się państwo (Sułkowska 1990, s. 63).

Powołanie rządu Grabskiego nastąpiło w trudnym momencie dziejowym, dlatego kwestie gospodarcze zeszły na drugi plan. Na pierwszym znajdowała mobilizacja i wojna z Rosją sowiecką. Gdy rząd Grabskiego upadł, powołano Rząd Obrony Narodowej Wincentego Witosa, ale ministrem skarbu pozostał dalej Grabski.

Konieczność zwiększenia nakładów na prowadzenie wojny wymusiła wprowadzenie nowego podatku dochodowego i majątkowego. Podatek uderzał przede wszystkim w warstwy najuboższe, ustalając wysokie obciążenia finansowe. Mimo potrzeby ratowania skarbu państwa, szczególnie w obliczu ogromnych potrzeb wojennych, IKC atakował pomysłodawcę tych obciążeń: „Ustawę tę układał człowiek, który się zupełnie nie liczy z życiem realnym” (Nowe..., 1920). Nawoływał też błagalnie o uwolnienie mieszkańców Polski od „p. Grabskiego”. Kolejnym argumentem, który został wytoczony przeciw ministrowi, było fiasko prowadzonych przez niego ustaleń na konferencji w $\mathrm{Spa}^{3}$. Zgodnie z nimi Polska miała zrzec się roszczeń do Śląska Cieszyńskiego, w zamian Wielka Brytania miała powstrzymać Rosję sowiecką na wytyczonej tzw. linii Curzona, co miało uchronić ziemie rdzennie polskie od zalewu przez bolszewików. Niestety, porozumienie w Spa okazało się fikcją (Kto..., 1920; Co p. Grabski..., 1920; P. Grabski musi..., 1920). Rozwiązania przyjęte na tej konferencji negatywnie oceniła część sceny politycznej (Witos 1964, s. 268; Skodlarski 2015, s. 19). Grabskiemu zarzucono dbanie o interesy ekonomiczne Czechów, kapitału niemieckiego i żydowskiego (Pan minister..., 1920), wpuszczenie

3 Konferencja odbyła się od 5 do 16 lipca 1920 roku. Uczestniczyli w niej przedstawiciele państw Ententy, innych państw europejskich oraz Polski. Jednym z ustaleń była m.in. zgoda Polski na oddanie Wilna Litwie. 
na polski rynek francuskich towarów luksusowych (Pan Wł. Grabski..., 1920), nazywano go „szkodnikiem narodowym” (Jak pan Grabski..., 1920), oskarżano o „wyprzedaż Polski” („Wysprzedaż..., 1920). Na ówczesne nastroje społeczne wpływały także duże koszta kampanii wojennej. Straty ludnościowe były zastraszające. Poległo około stu tysięcy ludzi, liczba rannych wynosiła niemal tyle samo. Bardzo źle przedstawiały się finanse kraju. „Kurs marki polskiej w okresie wojny spadł z 15 do 400 mkp za dolara” (Sułkowska 1990, s. 72). Informacja, że minister ustępuje w wyniku odebrania mu poparcia ze strony Narodowej Demokracji i przejścia do opozycji wywołała w redakcji $I K C$ ulgę i zadowolenie. „Uczucia ulgi, radości i zadośćuczynienia ogarnęły wszystkie stronnictwa sejmowe. Minister skarbu Grabski ustępuje” (Minister Grabski..., 1920).

$I K C \mathrm{z}$ ogromną ulgą żegnał ministra skarbu. Zrobił to, przytaczając opinie innych pism, jednak tylko negatywne. Grabski sprawował urząd ministra skarbu do 25 listopada 1920 roku. Witając nowego ministra, Jana Steczkowskiego, dziennik pisał:

Rozumiemy, że nie będzie on cudotwórcą i nie potrafi w mgnieniu oka wyczarować nam zdrowej waluty i usunąć deficytu budżetowego: ale ufamy, że położy wreszcie kres dotychczasowej dyletanckiej gospodarce finansowej, która wiodła Rzeczpospolitą wprost do katastrofy (Nowy..., 1920).

Do końca 1920 roku Władysław Grabski nie był już obiektem ataków prasowych Kuriera.

\section{Podsycanie dzielnicowych antagonizmów}

Ilustrowany Kurier Codzienny przyjął krytyczną postawę wobec wielu rozwiązań wprowadzanych przez rządy, uznawał je za szkodliwe i niekorzystne dla społeczeństwa. By je powstrzymać, wykorzystywał różne narzędzia walki i strategie polityczne. Na początku 1919 roku w stosunku do rządu Ignacego Paderewskiego pojawia się określenie „rząd warszawski”. „Bolszewicy rosyjscy przysłali rządowi warszawskiemu warunki pokojowe” (Bolszewicy..., 1920). W ten sposób krytykowany gabinet przestawał w zamierzeniu dziennikarzy IKC być rządem polskim, a stawał się „rządem lokalnym”, co miało wywoływać nieufność i podejrzliwość wobec niego. Pozbawianie rządu legitymizacji ze strony całego społeczeństwa było jedną $\mathrm{z}$ metod walki politycznej stosowanej przez IKC.

Strategia polegała na korzystaniu z istniejących już antagonizmów, stereotypów czy funkcjonujących negatywnych ocen warszawskich środowisk rządowych i administracyjnych. Pojawiały się więc teksty przepełnione informacjami o warszawskim dyletanctwie, „chciwych rękach warszawskich” (Zwycięstwo..., 1919), złym rządzeniu, niedbałości czy braku rzetelności oraz staranności. Każde zdarzenie mogące potwierdzić te stereotypy było z wyjątkową dokładnością przedstawiane czytelnikom dziennika. Przykładem może być sposób wytłumaczenia czytelnikom, dlaczego Kraków ma problemy z zaopatrzeniem w ziemniaki. Według IKC, 
który przeprowadził dochodzenie w tej sprawie, „wagony z ziemniakami, będące w drodze do Krakowa, «zarekwirował» w Skalmierzycach «Wydział Zaopatrzenia m. Warszawy». Zarekwirował? No, słowo to jest zbyt oględne. Należałoby powiedzieć: zagrabił albo ukradł” (Jak „Wydział..., 1920). Na podstawie informacji z krakowskiego magistratu IKC informował, że rządy warszawskie odmawiały Krakowowi nafty, spirytusu i cukru. Redakcja informowała, że na te kwestie zwróciła uwagę krakowskim posłom. Ostrzegała: „Niech Warszawa i jej referenci z ogniem nie igrają" (Rządy..., 1920).

W tak sformułowanych ocenach sytuacji pojawiają się wezwania do przekreślenia procesów centralizacji i unifikacji państwa polskiego. IKC, niezadowolony z podejmowanych działań przez „warszawskie rządy”, wprost nawoływał do gruntownego oczyszczenia urzędów oraz nauczania pracy tamtejszych urzędników, bo „w przeciwnym razie będziemy żądali najdalej idącej autonomii dla Małopolski” (Jak „Wydział..., 1920). Oskarżenia o złe rządzenie w Warszawie wynikały ze złej sytuacji, w jakiej znalazła się Małopolska: „Okazuje się, że centralizacja Galicji z Warszawą była przedwczesną $\mathrm{i}$ jedyny ratunek dla Małopolski jest uzyskać dla niej pewną niezależność gospodarczą i administracyjną" (Pomysty..., 1919). Podnoszono, że odseparowanie się zdrowych kresowych prowincji polskich od Warszawy staje się coraz aktualniejsze (Żądamy..., 1920). Nawoływanie do separatyzmu przeraża samą redakcję $I K C$, która następująco tłumaczy swoje postępowanie czytelnikom: „A nie jest to jakiś separatyzm, nie jest to brak poczucia łączności narodowej, ale objaw zdrowego instynktu samozachowawczego, który wobec upartego samobójcy nie chce razem z nim ginąć" (Nakaz..., 1919). Dziennik argumentował, że centralizm rządowy jest zawsze zły i szkodliwy, a decentralizacja i urządzenie państwa na podstawie silnych autonomicznych prowincji powinny być zawsze programem rządowym. Jednak „wobec warszawskiego nieuporządkowania, powiedzmy wprost: bezładu - to hasło staje się czymś więcej, niż programem politycznym, bo wprost nakazem moralnym" (Nakaz..., 1919). W Warszawie miała występować tendencja do centralizowania wszystkiego, dlatego Małopolska musiała się bronić przeciw warszawskiej niesumienności biurokratycznej. Aprowizacja Małopolski nie mogła zależeć od warszawskiej biurokracji, nawet gdyby ona była sprawniejsza.

Żądamy przywrócenia pełnej autonomii i pełnego samorządu - z wykluczeniem wszelkich central warszawskich! - Bo tylko tym sposobem powstrzymamy postęp grożącej anarchii i zapewnimy sobie sanację stosunków, lepszą aprowizację, zmniejszenie drożyzny, sprawniejszą, uczciwszą administrację (Żądamy..., 1920). 


\section{Obrona interesów Małopolski motywem działań IKC}

Krytyczne stanowisko wobec elit i biurokracji warszawskiej, a także nawoływanie do podejmowania kroków separatystycznych dziennik tłumaczył obroną interesów ekonomicznych mieszkańców Małopolski. Od samego początku działań unifikacyjnych skupionych wokół walut $I K C$ podnosił, że proponowane rozwiązania godziły w interesy ekonomiczne mieszkańców. Pisał z troską:

Zachodzi niebezpieczeństwo, że majątek narodowy Galicji ulokowany w koronach, zostanie zniszczony. [...] Rząd w ogóle rozpatrując sprawy ogólnopaństwowe bierze pod uwagę tylko interesy Kongresówki, a więc prowincji zupełnie w każdej dziedzinie zanarchizowanej [...] (Pomysty..., 1919).

Dziennik nie poprzestawał tylko na umieszczaniu krzykliwych tytułów sugerujących konieczność obrony własnych interesów. Ukazywały się teksty pokazujące negatywne skutki dla najuboższej ludności przelicznika walut zaproponowanego przez Władysława Grabskiego.

Dziennik tłumaczył czytelnikom, że Małopolska jest dzielnicą najbardziej politycznie uświadomioną, gotową do uczestnictwa w procesie zjednoczenia państwa. W dzielnicy tej nie ma tendencji partykularnych czy separatystycznych, a wprost przeciwnie, Małopolska ofiarnie i zgodnie podporządkowała się władzy centralnej. Jednak zamiast wdzięczności spadły na nią z tego tytułu wyłącznie nieszczęścia w postaci niekorzystnych rozwiązań ekonomicznych i warszawskiego centralizmu oraz niedołęstwa administracyjnego. Przypominano sytuację Galicji pod „warszawskimi rządami”. Rysowany obraz przedstawiał się w tych tekstach wyjątkowo jednoznacznie. Małopolska pełna poświęceń stała się ofiarą warszawskich nieudolnych elit. Dlatego dziennik przypominał: „Rząd warszawski jednak i społeczeństwo w Kongresówce jeszcze w najmniejszej mierze nie zdaje sobie sprawy, jak ciężkie szkody niedołężny centralizm warszawski wyrządził Galicji i wyrządza co dzień” (Żądamy..., 1920).

\section{Podsumowanie}

Przestawiona analiza ukazuje stanowisko krakowskiego dziennika $I K C$ wobec działań prowadzących do ujednolicenia walut oraz polityki finansowej prowadzonej przez rządy Ignacego Paderewskiego, Leopolda Skulskiego oraz Władysława Grabskiego. Przedstawia także stosunek dziennika do trzech ministrów skarbu: Stanisława Karpińskiego, Leona Bilińskiego oraz Władysława Grabskiego. W największym stopniu krytyka IKC dotyczyła działalności ministra i premiera Grabskiego.

Zdecydowane negatywne stanowisko Kuriera wobec walutowych działań unifikacyjnych wynikało z przyjętego przez Władysława Grabskiego niekorzystnego dla Małopolski przelicznika kursu marki polskiej i korony. Artykuł pokazuje skalę i poziom dziennikarskich zarzutów, natężenie kampanii prowadzonej w sposób 
brutalny i systematyczny. Działania te, nazywane przez IKC obroną interesów mieszkańców, charakteryzowało nie tylko wykorzystywanie argumentów ekonomicznych, ale także korzystanie z demagogii i projektów separatystycznych. Wykorzystywanie w prowadzonej kampanii istniejących odmienności i różnic pomiędzy poszczególnymi częściami terytorium Polski świadczy o trudnościach, na jakie natrafiało odrodzone państwo. Tak częste i bezwzględne sięganie do haseł odłączenia czy daleko posuniętej autonomii Małopolski świadczy o istnieniu ogromnych różnic kulturowych i gospodarczych w społeczeństwie. Sugeruje również występowanie pokładów stereotypów i uprzedzeń, wśród których szczególnie widoczne jest wykorzystywanie istniejącej niechęci wśród Małopolan do mieszkańców Warszawy. Można też to odczytywać jako typowy negatywny stosunek peryferii do władzy centralnej.

Natężenie oraz skala ataków świadczą o znaczeniu ekonomicznym ujednolicenia walut dla mieszkańców Małopolski, do których odwoływał się IKC. Pokazuje także bezwzględną walkę prasy międzywojennej o zdobycie i utrzymanie czytelnika. W tej kwestii Kurier stosował skuteczne strategie. Obrona interesów małopolskich czytelników wraz z widoczną bezpardonowością ataków prasowych, dodatkowo wsparta elementami narodowymi oraz sensacyjnymi, stanowiła sposób docierania do jak najliczniejszego grona odbiorców.

Nie bez znaczenia pozostaje też osobiste zaangażowanie polityczne Mariana Dąbrowskiego, dążącego do uzyskania miejsca w parlamencie. $Z$ tej m.in. przyczyny od 1918 roku utrzymywał on bliskie związki ze światem polityki (Borowiec 2005d), a także wykorzystywał nie tylko swój dziennik, lecz także opierał się na dobranym zespole redakcyjnym reprezentującym wszelkie ówczesne ideologie polityczne (Borowiec 2018, s. 193).

\section{Bibliografia}

(p) (1924). U progu Nowego Roku. IKC, nr 2, s. 2.

„Wyprzedaż Polski” (1920). IKC, nr 268, s. 3.

1 korona $=83$ fenigi! Bańki mydlane p. Grabskiego pryskają (1919). IKC, nr 353, s. 1.

1 marka = 1 korona!!! Wielka przegrana polityki p. Grabskiego (1920). IKC, nr 5, s. 2.

Bańdo A. (2003). Marian Dąbrowski i legenda Ilustrowanego Kuriera Codziennego. W: J. Jarowiecki (red.). Kraków-Lwów. Książki - czasopisma - biblioteki XIX i XX wieku (s. 195-206), t. 4. Kraków.

Bolszewicy rosyjscy przysłali rządowi warszawskiemu warunki pokojowe" (1920). IKC, nr 4, s. 1 . Borowiec P. (2005a). Między sensacją a nauką. Obraz produktów krakowskiego wydawnictwa i koncernu prasowego Ilustrowany Kurier Codzienny (1910-1939). Kraków.

Borowiec P. (2005d). Polityczna działalność Mariana Dąbrowskiego. Zeszyty Prasoznawcze, nr 1-2, s. 105-122.

Borowiec P. (2003). Podstawy finansowe i prawne wydawnictwa i koncernu Ilustrowany Kurier Codzienny (1910-1939). W: J. Jarowiecki (red.). Kraków-Lwów. Książki - czasopisma - biblioteki XIX i XX wieku (s. 224-240), t. 4. Kraków. 
Borowiec P. (2005b). Jesteśmy głosem milionów. Dzieje krakowskiego wydawnictwa i koncernu prasowego Ilustrowany Kurier Codzienny (1910-1939). Kraków.

Borowiec P. (2005c). Obraz Rosji Radzieckiej, Czechosłowacji i Niemiec na łamach Ilustrowanego Kuriera Codziennego w latach 1918-1939. W: H. Kosętka (red.). Kraków-Lwów. Książki - czasopisma - biblioteki (s. 556-569), t. 7.

Borowiec P. (2010). Przegląd wydawnictw koncernu prasowego Ilustrowany Kurier Codzienny, W: G. Wrona, P. Borowiec, K. Woźniakowski (red.). Ilustrowany Kurier Codzienny. Księga pamiątkowa w stulecie powstania dziennika i wydawnictwa 1910-1939 (s. 45-65). Kraków-Katowice.

Borowiec P. (oprac.) (2018). Jan A. Stankiewicz. Szkice do pamiętnika. Kraków.

Cały gabinet Skulskiego podał się do dymisji. Naczelnik Państwa dymisję przyjął (1920). IKC, nr 158, s. 1.

Co p. Grabski podpisał w Spaa? (1920). IKC, nr 297, s. 3.

Czy walczymy o koronę? (1920). IKC, nr 16, s. 1.

Dokąd zdążamy (1912). IKC, nr 152, s. 1.

Dr.J.H. (1919). P. Grabski pozbawi nas Śląska. IKC, nr 352, s. 7.

Drozdowski M.M. (2002). Władysław Grabski, Rzeszów.

Dziki S., Rogoż M. (2010). Marian Dąbrowski i jego opus vitae - koncern IKC (próba kalendarium). W: G. Wrona, P. Borowiec, K. Woźniakowski (red.). Ilustrowany Kurier Codzienny. Księga pamiątkowa w stulecie powstania dziennika i wydawnictwa 1910-1939 (s. 66-84). Kraków-Katowice.

Głowacki W. (2018). Pieniądz i państwo [http://www.gazetakrakowska.pl/artykul/6375392,pieniadz-i-panstwo,id,t.html; 25.05.2018].

Grata P. (2009). Monopole skarbowe w polityce podatkowej Drugiej Rzeczypospolitej. Rzeszów. Jak „Wydział zaopatrywania m. Warszawy” rabuje ziemniaki, zakupione przez Kraków (1919). IKC, nr 353, s. 1.

Jak pan Grabski Czechom Śląsk darował. A teraz ich przemysłem się zatroskał (1920). IKC, nr 258, s. 2. Jak powstał nowy gabinet (1920). IKC, nr 172, s. 6.

Kowalski W. (2018). Od marek po „królewskie” złote. Polski pieniądz papierowy w XX wieku [http://natemat.pl/136013,od-marek-po-krolewskie-zlote-polski-pieniadz-papierowy-w-Xx-wieku; 25.05.2018].

Kto nas uwolni od p. Grabskiego? (1920). IKC, nr 25, s. 1.

Małopolska broni się przeciw eksperymentom p. Grabskiego. Wybitni znawcy domagają się relacji 1 marka = 1 koronie. Znieść krzywdzące rozporządzenia (1920). IKC, nr 1, s. 1.

Minister Grabski ustępuje! (1920). IKC, nr 319, s. 6.

Minister skarbu i jego pożyczki. Jak p. Grabski zaszkodził „Pożyczce Odrodzenia” (1920). IKC, nr 165 , s. 1.

Nakaz moralny (1919). IKC, nr 184, s. 1.

Nowe podatki p. Grabskiego grożą ruiną warstwom najbiedniejszym (1920). IKC, nr 245, s. 1.

Nowy gabinet już utworzony. Władysław Grabski premierem (1920). IKC, nr 172, s. 1.

Nowy minister skarbu (1920). IKC, nr 327, s. 2.

P. Grabski musi ustąpić (1920). IKC, nr 319, s. 1.

P. Grabski tworzy pasek spirytusowy (1920). IKC, nr 5, s. 2.

Pan Grabski mówi... nieprawdę (1920). IKC, nr 5, s. 2.

Pan minister Grabski opiekunem niemiecko-syjonistycznych spekulantów (1920). IKC, nr 259, s. 2. 
Pan Wł. Grabski przegrał swoją tekę ministerialną (1920). IKC, nr 281, s. 3.

Państwowość (1916). IKC, nr 253, s. 1.

Po ustąpieniu p. Bilińskiego (1919). IKC, nr 344, s. 1.

Polska zmartwychwstaje (1918). IKC, nr 186, s. 1.

Pomysły warszawskie grożą Małopolsce gospodarczą i finansową ruiną (1919). IKC, nr 178, s. 1.

Precz z koroną. Kiedy dadzą nam ujednolicony pieniądz polski? (1920). IKC, nr 32, s. 4.

Przyspieszyć unifikację waluty w Polsce albo niech min. Karpiński ustąpi! (1919). IKC, nr 157, s. 3.

Rozporządzenia skarbowe, które budzą wielkie obawy i wielkie wątpliwości (1919). IKC, nr 352, s. 6.

Rządy warszawskie odmawiają nam nafty, spirytusu i cukru (1920). IKC, nr 25, s. 5.

Skład nowego gabinetu (1919). IKC, nr 342, s. 2.

Skodlarski J. (2015). Władysław Grabski jako ekonomista (1874-1938). Łódź.

Skutki relacji p. Grabskiego. Strajk kolejarzy lwowskich trwa (1920). IKC, nr 6, s. 2.

Sułkowska W. (1990). Twórcy polskiej myśli ekonomicznej. Władysław Grabski. Kraków.

T.zw. „Gabinet konieczności państwowych” (1920). IKC, nr 173, s. 1.

Witos W. (1964). Moje wspomnienia, t. 2. Paryż.

Witos, Grabski i endecja spółka, która obrabowała Małopolskę (1920). IKC, nr 18, s. 1.

Zieleń M. (2010). Sytuacja gospodarcza Polski w okresie wielkich reform Władysława Grabskiego.

W: Reforma skarbowo-walutowa Władysława Grabskiego - założenia, realizacja, efekty. Suwałki. Zwycięstwo „Warszawy” ale klęska Polski (1919). IKC, nr 339, s. 1.

Żądamy gospodarczego i administracyjnego wyodrębnienia Galicji (1920). IKC, nr 55, s. 1.

\section{STRESZCZENIE}

Scalanie państwa polskiego po 1918 roku wymagało szybkich i zdecydowanych działań, determinacji w przezwyciężeniu zaborczych odmienności i partykularyzmów. Artykuł przedstawia stosunek Ilustrowanego Kuriera Codziennego, uważającego się za reprezentanta interesów mieszkańców Małopolski, do ujednolicenia walut przeprowadzonego w 1919 roku. Ukazuje skalę trudności zmian walutowych oraz całokształt krytyki, jakiej byli poddani autorzy reformy. Koncentruje się na prasowej krytyce na łamach $I K C$, sposobach zwalczania niekorzystnych rozwiązań ekonomicznych oraz proponujących je polityków. Artykuł skupia się szczególnie na stosunku IKC do Władysława Grabskiego pełniącego funkcję ministra skarbu oraz premiera rządu w analizowanym okresie, czyli od 1 stycznia 1919 do końca 1920 roku.

Słowa kluczowe: wymiana walutowa 1919 roku, odbudowa państwa, Władysław Grabski, prasa przedwojenna, Ilustrowany Kurier Codzienny 